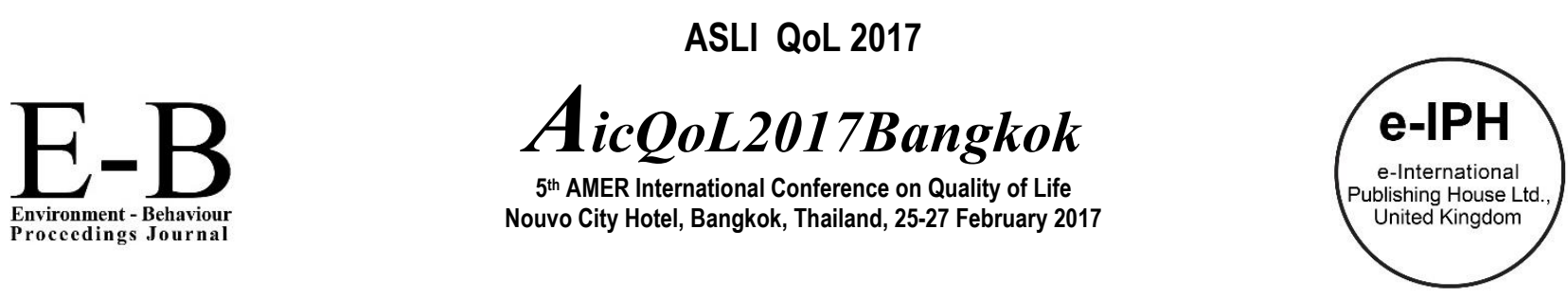

\title{
Attributes of Housing Mismatch Framework in Urban Areas
}

\author{
Ahmad Fawwaz Saleh 1*, Ting Kien Hwa 2, Rohayu Ab Majid ${ }^{3}$, Muhammad Hilmi Mohamad@Masri 4 \\ 1 Department of Postgraduates Studies, Faculty of Architecture, Planning, and Surveying, Universiti Teknologi MARA (UiTM), 40450 Shah Alam, Selangor, Malaysia*,
}

\begin{abstract}
Housing industry is constantly faced with various phenomena of the real estate market. The gamble between elements of supply and demand in the housing industry segmentation is shaping the market situation. However, the expected balance between supply and demand is difficult to achieve, even in the long run. Therefore, this study aims to examine the key factors that contribute to the level of demand in a real estate market. Respondents representing buyers of area studies have questioned on their consideration of the factors that might influence their decision in-house purchasing. Three main components such as housing regulation, geographical spatial location, and housing product have been expanded with seven subcomponent and 37 elements. Data were collected through a preliminary survey from sample population at study area of Wangsa Maju, Kuala Lumpur, Malaysia, which experienced with housing mismatch phenomena. Data has been analysed by using SPSS software in generated the mean score for each of element. The results indicate that 18 of the 36 items reported average rating at values more than 3.0. This shows that three main components of the study indeed affect home buyers as well as lead to the level of housing demand in the housing market. Documentation of this aspect in urban areas will make local communities, government, and private institution appreciate and improvise better decision-making for residential development to decrease a gap. Thus, better enhancement in quality of life by the stakeholders will create a strong sense of community identity and belonging to the places.
\end{abstract}

Keywords: Housing mismatch; Urban Areas; Dissimilarity; Quality of life

ISSN: 2398-4287@ 2017. The Authors. Published for AMER ABRA by e-International Publishing House, Ltd., UK. This is an open access article under the CC BYNCND license (http://creativecommons.org/licenses/by-nc-nd/4.0). Peer-review under responsibility of AMER (Association of Malaysian Environment-Behaviour Researchers), ABRA (Association of Behavioural Researchers on Asians) and cE-Bs (Centre for Environment-Behaviour Studies), Faculty of Architecture, Planning \& Surveying, Universiti Teknologi MARA, Malaysia.

\subsection{Introduction}

A wide-ranging thoughtful of housing mismatch is essential for the country to deal with the failing of housing demand and shelter supply in macroeconomics perspectives. The significant problem arises when there are people is unaffordable to meet the current market. Those people were somehow facing difficulty in matching with their profiles and preferences. However, besides affordability, there are other attributes that contribute to existences of housing mismatch. For instance, an inconsistency of housing regulation, spatial geographical location, and determination in housing product factors. Housing mismatch will exist in a particular country or region, and arguably the imbalance between demand and supply is still going to happen, whether taking into account that there are surplus or shortage. The questioned is not to know whether there is an existence of this imbalance but on what circumstances and aspect that lead to such imbalance to the areas.

All these features provide high proportion to housing mismatch. Inequality of the aspect with demographic profiles in particular places will lead to negative impact toward housing industries. Most of the people have their own issues that restrict them for not buying a house. And, typically, most urban areas ended up with different attributes of housing discrepancy. It exists due to the dissimilarity of preferences, profiles, and people behaviour.

In light of recent event in housing development, it is becoming tough to ignore the existence of this phenomenon. Since it was reported in the previous year, (KRI, 2015; Cagamas, 2013; NLIHC, 2016) disparity of housing demand and supply had been attracting a lot of interest by a few kinds of research in recommending what the best for the people and other parties.

\footnotetext{
${ }^{*}$ Corresponding author. Tel.: 60194189454

E-mail address: ahmadfawwaz91@yhoo.com
}

(C) 2017. The Authors. Published for AMER ABRA by e-International Publishing House, Ltd., UK. This is an open access article under the CC BYNC-ND license (http://creativecommons.org/licenses/by-nc-nd/4.0/). Peer-review under responsibility of AMER (Association of Malaysian Environment-Behaviour Researchers), ABRA (Association of Behavioural Researchers on Asians) and cE-Bs (Centre for Environment-Behaviour Studies), Faculty of Architecture, Planning \& Surveying, Universiti Teknologi MARA, Malaysia.

DOI: http://dx.doi.org/10.21834/e-bpj.v2i5.701 
The imbalance of housing demand and supply may give negative impact toward quality of life. From previous research, housing mismatch had been studied by looking into different standpoint. Such as unemployment and job accessibility (Gobillon et al. 2007). Others, racial residential concentration (Stoll et al. 2000), neighborhood effect and public housing (Dujardin, C. \& Goffette-Nagot, 2005). And many empirical studies hold the view that imbalance of housing to meet demand and supply were affordability issues. Even, KRI (2015), emphasizing the affordability of urban areas are the primary concern contribute to housing imbalance.

Research on the subject has been mostly restricted to limited comparison with others attributed. For example regulation, spatial geographical location and product delivered by the supplier. The other attributes supported by the late research of Kawabata (2003); Zhou, Wu, \& Cheng (2013) and Lisi (2015). All this element should be indicated together to find the exact phenomenon contributed to housing mismatch.

The term of accommodation mismatch is used in the full range of context including the measurement level of wealth, regulation, employment of societies, behaviours, location, and product factor. Moreover, by investigating the factor that contributes to housing mismatch, indirectly can help communities and responsible parties for understanding the essence of sustainable development. Furthermore, by facilitating this phenomenon, can create a sense of living and belong toward communities. Hamdan, Yusof, \& Marzukhi (2014) highlight that by improvising better quality of life it will create the strong sense of place to be live with. Afterwards, government or private institution can take action to improve the economics of life for the people.

This paper aims, to study the exact contribution lead to the imbalance of housing demand and supply in urban areas at Wangsa Maju, Malaysia. An absolute essential to housing inequality conditions is by determining the element that may contribute to the highest percentage of housing imbalance among urban communities. According to Ahmed, Shaqra, Badarulzaman, \& Roosli (2015), in achieving people housing needs is a basis of communities satisfaction thus will influence their quality of life.

\subsection{Objectives}

There are three main objectives regarding this topics, as a guidance along the study process;

1. To investigate the attributes for housing mismatch based on a review

2. To analyze profiles of people toward attributed that contribute to housing mismatch

3. To identify influences and relations of housing mismatch attributes in study areas.

\subsection{Literature Review}

\subsection{The factual situation that contributed to existence of housing mismatch}

Nowadays, urban and suburban areas still continuously in high demand of people in purchasing houses. On the other hand, the main issues exist when affordability delinquent was creating abandonment among communities. People keep arguing about the distribution of income and high market value of houses with their preferred location. The percentage of housing mismatch keep arise and directly creating unsatisfied among people especially toward affordability factors. There is evidence that housing mismatch plays a crucial role in creating less sense of belonging towards the places.

Apart from affordability, other factors that contribute to housing inequality between demand and supply were regulation, spatial geographical location and quality of the houses (Fawwaz, Saleh, Hwa, \& Majid, 2016). Ignorance of stakeholder in an arrangement of regulation may restrict people in buying houses. Meanwhile, lack of understanding on quality or product factor of houses and location of housing development contribute in widening the gap between demand and supply.

Even, Seelig \& Phhibs (2006) found the dramatic result to understand low-income renters and residential affordability. The article observes that low-income families often did not choose areas that had poor quality in amenity and location measures. In consequence, the research found, there is an essential consideration in addressing needs or preferences for housing features, location, and proximity to services and facilities was a priority even though such choices resulted more on housing budget.

Ignorance of resident upon the management of their living places, vandalism and crime are one of the factors that show a shortage in the sense of belonging toward people with their places. They seem don't fill wanted to take care their own places because of this phenomenon. Hamdan et al., (2014) stated that quality of life and social well-being are associated with the ability of people which disclosed with their surroundings, felt connected and have a strong sense to stay. According to Hui, Zhong, \& Yu (2015), it is prominence to studies housing mismatch looking upon people income and housing profiles. This research aims to find out the problem arise by people from looking into this three-factor of housing gap. Thus, it will create the consciousness of private and government in helping people to create their sense of belonging to their living places.

\subsection{The theoretical framework model indicator for housing mismatch}

Housing affordability is frequently assessed only in term of economic viability. Other important parts, such as sustainability, housing location, and quality are sometimes overlooked. Across certain geographic areas, the key relationship determining a discrepancy could be distanced from the city, inter-city of public transportation, and accessibility to the highway. To assisted the variables, $A$. Hamid Mar (2006) use quality of the product, landscape, accessibility, facilities and certain demographic profiles as a key to segmenting the market of local residences. On the other hand, the regulation could be the factor that may contribute to the inability of housing supply to meet demand expectation. Thus, it indirectly brings to the high percentage of housing mismatch.

Next, Some of the people having difficulty in meeting private regulation conducted by the financial institution and developer, but some facing the problem with government requirement. As refer from previous research by Fawwaz et al., (2016) the conceptual 
framework of housing mismatch had been introducing to represent the initial stage of imbalance between housing demand and supply. However, there are little-published figures on the indicators in measuring housing discrepancies (fig. 1). The researcher had enhanced a better understanding of the signs. Thus, it will recognise the key factor that influences a decision making of the purchaser to buy houses in the study area. Also, on searching for another element that causes people refused to purchase the houses, an extensive study should be done and do not just rely on market review, but, also depend on their preferences and choice instead;

\subsubsection{Affordability}

The studies indicate that the income, housing prices and supply of affordable housing in the areas directly restrict them to buy houses. However, those studies are still lacking in reviewing other factors of affordability that may result in restriction for the buyers in purchases houses. In the meantime, Fawwaz et al., (2016), emphasize that the majority of people from middle-income group trapped in the range of middle group requirement, they are not qualified to buy low and medium houses. Apparently, this is not derived from affordability issues but comes from the demand made by the authority in purchasing houses. The indicator to measure this part of housing disparities is by looking into their demographic profiles and market value provided by housing developers and secondary market.

\subsubsection{Regulation}

Regulation under private requirement is well known as a crucial procedure in proceeding with buyer intention to purchase residential properties. There are a lot of requirement should be prepared by the individual either for the sake of the bank requirement or standard of procedure deemed by a developer. Furthermore, regulation in housing residential would be appropriate to measure in knowing issues faced by the people (Thalmann, 2003). The noticeable requirement needed by the bank to approve a housing credit is qualification and proof of incomes toward to indicate the range of loan amount available for the borrowers. Property edge (2016) October 7, describe the element that needs to be prepared by borrowers in the interest of proceeding with the home purchase. For instance, the bank requires, credit history, income, interest rate, loan tenure, a margin of financing, joint borrower and for developer requirement there is a standard to comply which are booking fees, professional fees, and cash deposit.

For a government institution, they have their owned code of conduct for approving affordable houses for an individual. On the other hand, under government regulation, the people could explore the various schemes. Such as distribution of Skim Rumah Pertamaku and recently, MyDeposit scheme. The mismatch may exist due to bureaucratic procedures, the location of affordable houses and so on. All this requirement is stated under the regulation part that may bring to a high proportion of housing distinction. Policies, procedures and incentive related to housing supply are all reasons why new housing supply is unresponsive to market condition (Bramley, 2007). Therefore, by recognizing the factual issues of inequality enable for the stakeholders review the regulatory imposed by themselves

\subsubsection{Spatial Geographical Location}

For the location part, housing discrepancy may exist due to the people who cannot hunt for strategic location preferred by them. Homebuyers, who search affordable homes in the community-centric environment need to look under three aspect of location attributes. Firstly, strategic location, secondly, environmental area and next are, established location. Abdullah (1992) supported this distinct type of location to acknowledge the exact concern of people in making decision of buying houses. A. Hamid Mar, (2006); Nawawi, (1999); Safian, Nawawi, \& Sipan, (2014) also separated the aspect of location for several determination of research.

This is importance to meet the need of people in so many angles of area preferable. Apparently, for distance, accessibility of highway, availability for amenities and allocation of site layout are defined as the strategic location that was looking forward to the demand. For those who are more preferable for the aspect of environmental location, there are people who prefer to live far from the city, more conducive environment, and communal lifestyle with its beautiful view of the lake and lush green surrounding. Besides, there are other people who concern more on established location, which is more prefer on the popularity of the place, specialization of the areas and its topography. For popularity places, is define for those who have feel the sense of reputation to such area by ignoring whether it is strategic or not. There are still a lot of demand to live in the city until the ignorance of traffic congestion and pollution are come to pass. However, for specialization aspect, is defined as the specific area or an area that focus on something. Such as, Seksyen 7, Shah Alam well known as an education centre, for Cyberjaya, Selangor was known as IT centres and certain places that were well known as industrial development.

\subsubsection{Product Factor}

Product attributes are one of the other factor contributing to a high percentage of housing mismatch in public perspectives. The internal and external factor of the product seems to be importance in given people satisfaction toward their preferred houses. People were having a high relationship in determining housing product (Ariff, Omar, \& Mohd, 2016). Bogdon \& Can (1997) criticized the existing of research of affordability that is focusing on housing price rather than quality and housing condition. Even today, Mulliner et al. (2013) and Ariff et al. (2016) still critiqued on the majority of tools that used to assess affordability have little or no regard to housing quality, location, and neighbourhood characteristic. In the meantime, product factors from a developer view, they have to concern more on competitors in developing the houses. They have to highlight their difference with others private.

According to Streimikiene (2014), housing indicator that related to the quality of life is by measuring housing quality with environment and housing expenditure burden. Meanwhile, Hilmi \& Hadi, (2016) found distinct attributed to determine product factor 
under circumstances of qualities and neighborhood characteristics. Taken together, these findings suggest a role for product quality in promoting product element attributes.

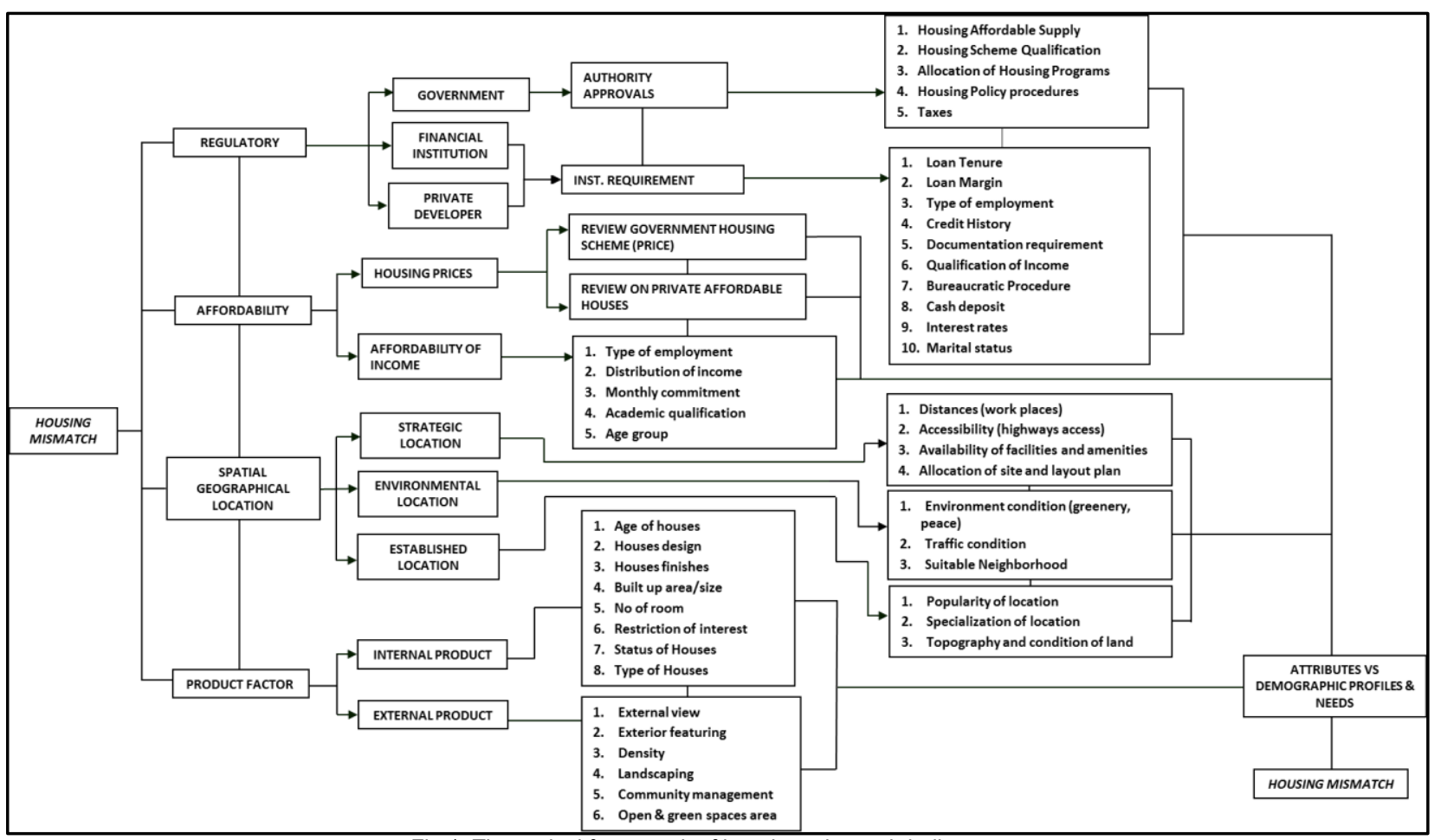

Fig 1: Theoretical framework of housing mismatch indicators

From previous literature review and discussion of housing mismatch, the figure above shows an indicator and guidelines to measuring housing incompatibility. The interrelationship between these situations is essential to indicate the common problems faced in the study area. The hypothesis review that, these four main issues comes from a discussion in various authors and research are relevant to studies for public viewpoints. However, there are additional factors to be considered in this aspect when looking into perspectives of a supplier. Such as from developers and financial institution.

\subsection{Research Methodology}

Based on the review above, a disparity between housing demand and supply are ones of the mechanism that can bring into chaos in certain areas. This studies purposely to compile all variables to indicate the type of housing mismatch phenomenon may exist in that selected areas. In the meantime, comprehensive analysis had to implement at study area in recognized the factual attributes that influence demand the citizen most.

In this research, a case study was conducted at Wangsa Maju, Malaysia by using simple random sampling with the total of 53 respondent. The study focus on Wangsa Maju that falling within the jurisdiction of the local authority of City Hall Kuala Lumpur (CHKL). The study area was chosen because the area is purposely developed to control the density of population among immigrant and urban sprawl prevailing in Kuala Lumpur. Initial development in the study area have allocated mixed development and was initially developed additional low-cost houses to cater existing development in a city centre. It also part of the goal in meeting a demand of low and middle-income group by early $80 \mathrm{~s}$. Because of that, it is indispensable for the study to know the situation for current years. These studies focus on the variable that encourages the urban communities decision making to own houses. And for affordability phenomenon, the measurement to indicate is by searching a distribution of income, monthly commitment and review on market value.

As a reminder, the differences areas contribute to a difference result of a situation. Having a difference demographic profiles will make them have to confront with a difference situation of housing mismatch. Eddie et al. (2005) emphasize the mismatch is relevant to studies on housing type, age structure, and household income. Correlation of this result will be developed in the final stage of this research.

Moreover, presentation of Pearson chi-square and average index had been carried out to test the relationship and its significances between demographic factors and attributes that contribute to housing mismatch in acquiring study at Wangsa Maju, Kuala Lumpur. Table 2 show the result of the analysis. Table 3 demonstrates the product from Pearson chi-square analysis on the status of living and attributes of housing discrepancies. The researcher used Statistical Package for Social Science Software (SPSS) to analyses the obtain data. Likert scaling and Cross tabulation analysis are also utilized for the purpose of the research. Secondary data have been collected from various working paper and the government report, especially from Kuala Lumpur Structure Plan 2020 
and Local Plan provided by the authority. The selected demographic feature had been recorded to identify the interrelationship with people preferences in particular area.

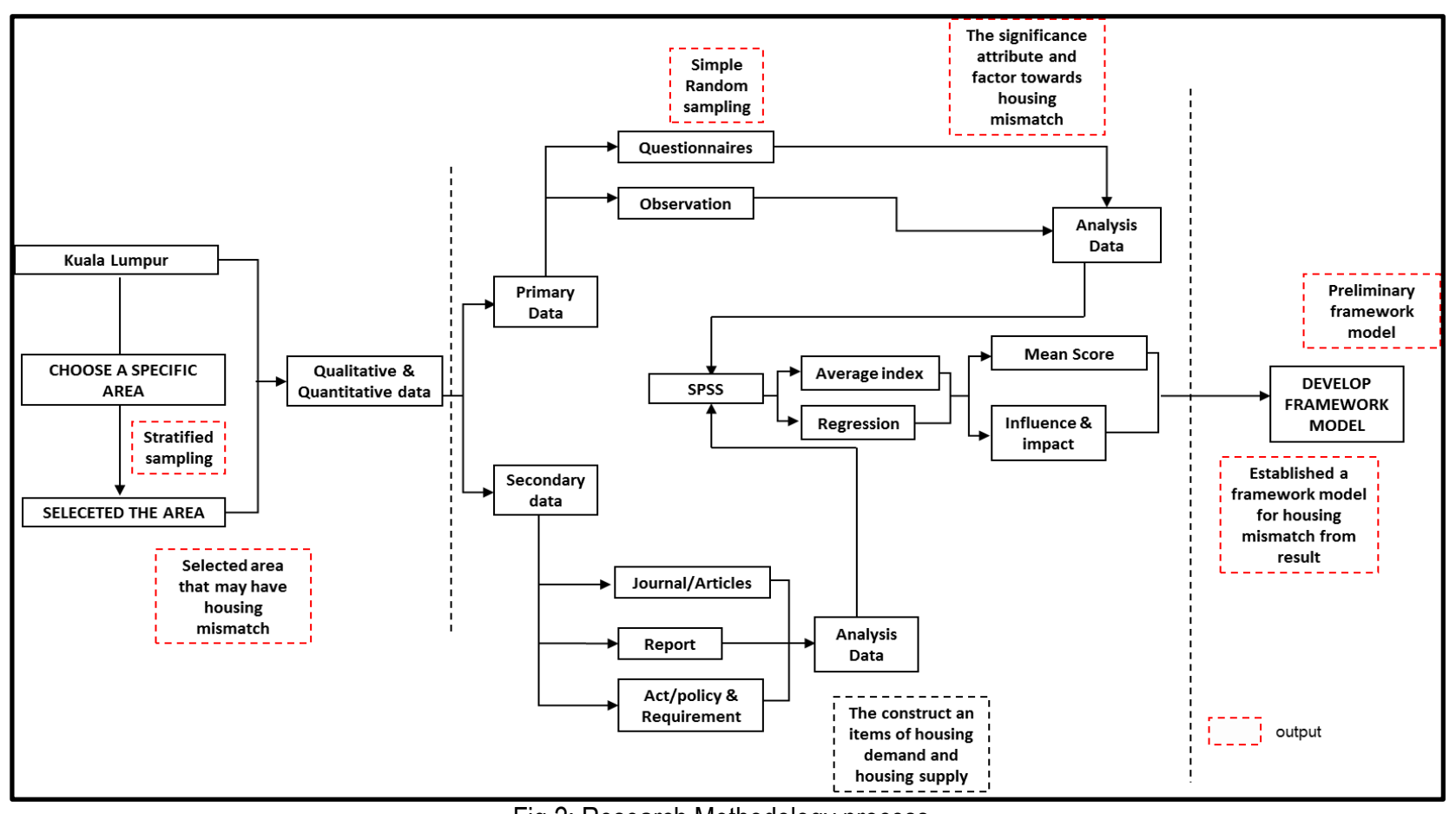

Fig 2; Research Methodology process

Lastly, for the limitation, this studies had subjected as preliminary studies with limited of time, and have faced difficulty in getting hundreds of respondent. However, for extended research, the studies will enhance more in developing strong support from the respondent in the areas.

\subsection{Findings}

\subsection{Relevant intersection of supply on demand in study area}

Wangsa Maju planned to accommodate a hundred thousand population with total 25, 970 dwelling unit comprising numerous type of affordable housing such as the apartment with medium and low-cost houses (Wan Nor Azriyati et al. 2007). The findings by the researcher reveal, Currently, about two third of homeowner in Wangsa Maju feels that intervention of authority and developer (PPPs) has provided low-income household as a mean of entry to provide additional numbers of homeownership in the study area. The studies reveal positive result for those who live in the areas. In the meantime, the articles from the edge (2015) also indicate the positive statement for the areas. Wangsa Maju had emerged as the new town for working people who do not want to spend too much time travel from home to workplaces (The edge, 2015).

Nowadays, Based on data provided by DBKL (2015) a total number of 28,197 unit for residential houses, with current population 115,484 people comprising all type of houses. The study areas were primarily developed as new suburban areas to accommodate the increasing number of demand in Kuala Lumpur. The planning was conducted successfully by gathering all development in one area and indirectly shown equality in society including construction of low-cost houses, middle and high-end properties. Likewise, (KLSP) 2000 highlight, city hall in the structure plan had been proposed to build a parliament of 126, 414 unit in Wangsa Maju-Maluri area by 2020. Other than that, proposal report provides by DBKL (KLSP, 2000) had announced that the local authority aims to provide equal distribution and develop spatial strategies for land use and development distribution. The quality of life needs to be achieved by focusing on housing distribution, safety environment and investment strategic in a city centre. Even, Wan et al. (2007) highlight, there is a high proportion of the owner-occupied feel proud being part of owning democracy group and conclude that housing policy in the study area had successfully assisted people to enter homeownership.

Next, other researchers have also concluded a positive result in a development of housing policy and indirectly give added value to the quality of life to live in the city. But, in the present, a new variable has been improved, all aspect must be accurately evaluated to ensure no community being isolated with current growth. Implementation of a new element is purposely to understanding more on demographic behaviour in the local community for the current situation. Thus, people can adapt themselves to the current changes and economic constraint.

Notwithstanding, General finding revealed, Wangsa Maju exposed to unhealthy activities such as crime and vandalism until it gets the attention of the government. According to the minister of housing (2011), Wangsa Maju was declared to as "hot zone" of crime by 
some official statement. Moreover, the constraint to the economic changes also may cause the issue of a buyer not to buy houses there, include an increasing land price that affects people from low and middle income. Besides, a recent transaction of new development in Wangsa Maju has boosted prices to between RM600 - RM700 (JPPH, 2016). Within the list of state housing market being assessed Kuala Lumpur had stand out as a severely unaffordable market with median multiple 5.4 respectively. (KRI, 2015).

\subsection{The cross-tab for demographic profiles at Wangsa Maju areas}

\begin{tabular}{|c|c|c|c|}
\hline \multirow[t]{2}{*}{ Demographic Profiles } & & \multicolumn{2}{|c|}{ Status of Living } \\
\hline & & Owner & Renter \\
\hline \multirow[t]{2}{*}{ Gender } & Male & 20.8 & 22.6 \\
\hline & Female & 15.1 & 41.5 \\
\hline \multirow[t]{2}{*}{ Status } & Single & 9.4 & 26.4 \\
\hline & Married & 26.4 & 37.7 \\
\hline \multirow[t]{5}{*}{ Age Group } & $18-20$ years & 3.8 & 132 \\
\hline & $21-30$ years old & 7.5 & 20.8 \\
\hline & $31-40$ & 11.3 & 17.0 \\
\hline & $41-50$ & 3.8 & 7.5 \\
\hline & 51 years \& above & 9.4 & 5.7 \\
\hline \multirow[t]{4}{*}{ Academic Qualification } & SPM and below & 3.8 & 26.4 \\
\hline & Diploma Holder & 20.8 & 20.8 \\
\hline & Degree \& Master Holder & 7.5 & 17.0 \\
\hline & PhD Holder & 3.8 & 0.0 \\
\hline \multirow[t]{4}{*}{ Type of Employment } & Government Institution & 7.5 & 9.4 \\
\hline & Private Institution & 15.1 & 45.3 \\
\hline & Own Business & 9.4 & 7.5 \\
\hline & Pensioner & 3.8 & 1.9 \\
\hline \multirow[t]{10}{*}{ Monthly Income } & RM 1500 \& below & 1.9 & 132 \\
\hline & RM 1501 - 2000 & 3.8 & 1.9 \\
\hline & RM $2001-2500$ & 1.9 & 5.7 \\
\hline & RM $2501-3000$ & 1.9 & 22.6 \\
\hline & RM $3001-3500$ & 11.3 & 9.4 \\
\hline & RM $3501-4000$ & 1.9 & 3.8 \\
\hline & RM $4001-4500$ & 3.8 & 0.0 \\
\hline & RM $4501-5000$ & 1.9 & 3.8 \\
\hline & RM $5001-6000$ & 1.9 & 1.9 \\
\hline & RM 6001 \& above & 5.7 & 1.9 \\
\hline
\end{tabular}

A total of 53 respondent for the preliminary survey at study areas, table 1 show a demographic profile among resident status for owner and tenant. As shown in Table 1, a majority of the respondent in the study area are in the status of renter or tenants (64.1\%), that is by adding the percentage of male (22.6) and female (41.5). This table also shows that most of the respondent in the circle who were married status $(37.7 \%$ ) still a tenant. This percentage shows there is some aspect that could cause these things happen. Other than that, the study areas show, a majority of the respondent in the category of SPM (26.8) and Diploma (20.8) holder, both contributed to the high percentage as a tenant in place. While only $20.8 \%$ among diploma holder act as an owner of the houses. As for the type of employment, a respondent in the private sector outstrip all the area as a person who was still renting a house that is by 45.3 per cent. Table 1 shows the most of the respondents' total monthly income is among the average of RM $2501-3000$ per month. And once again, a majority of the respondent in this stage are still trapped in issues of do not live as a homeowner. Only a few of them, have their own houses that are at most 11.3 percent of the salary between RM $3001-3000$.

\subsection{Average of overall attributes}

In Table 2, shows the average of the overall index for housing imbalance. The respondent was asked whether they agree or not with the implementation of private and public institutions in the aspect that contained in a diagram (Fig.2) above. The study was use based on a five point of Likert scale with respond ranging from strongly disagree (1) and strongly agree (5). The study will focus on the percentage of people that strongly disagree and agree with attributes provide by the supplier in particular areas.

The figure had been divided into several categories. Among these are regulation, spatial location, and product factor. The main character of regulation, which had split into two points of view, has shown encouraging results. Some aspect had shown average with more than 3.0. Such as loan margin (3.30), scheme qualification (3.36), procedure (3.36), and taxes (3.57). For spatial geographical location, seven elements indicate more than 0.3 . For instances, distance with 3.75 , Accessibility (3.81), availability of amenities and 
facilities (3.62), suitable neighborhood (4.32), the popularity of location (4.49), specialize location (3.19) and topography and condition of land with 3.09. Meanwhile, for product factor, seven of them indicate more than 3.0 under internal and external factor (Table 2).

Table 2: Average score for overall housing mismatch elements

\begin{tabular}{|c|c|c|c|}
\hline $\begin{array}{l}\text { ष्ठ } \\
\stackrel{0}{0}\end{array}$ & Main Attributes & Element & \\
\hline \multirow{13}{*}{ 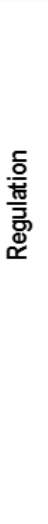 } & Private & Loan Tenure & 285 \\
\hline & Requirement & Loan Margin & 3.30 \\
\hline & & Credit History & 243 \\
\hline & & Interest rate & 260 \\
\hline & & Documentation Requirement & 255 \\
\hline & & Qualification of income & 247 \\
\hline & & Bureaucratic Procedures & 281 \\
\hline & & Cash Deposit & 283 \\
\hline & Government & Housing affordable supply & 275 \\
\hline & Requirement & Housing Scheme Qualification & 3.36 \\
\hline & & $\begin{array}{l}\text { Housing Scheme Document } \\
\text { Attachment }\end{array}$ & 270 \\
\hline & & Housing Programs procedure & 3.36 \\
\hline & & Taxes & 3.57 \\
\hline \multirow{10}{*}{ 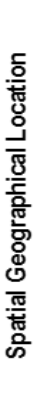 } & Strategic Location & Distances & 3.75 \\
\hline & & Accessibility & 3.81 \\
\hline & & Availability of Amenities \& Facilities & 3.62 \\
\hline & & Allocation of site \& layout plan & 281 \\
\hline & Environment & Environment condition & 2.36 \\
\hline & Location & Suitable Neighborhood & 4.32 \\
\hline & & Traffic condition & 242 \\
\hline & Establish Location & Popularity of the location & 4.49 \\
\hline & & Specialization of location & 3.19 \\
\hline & & Topography \& Condition of land & 3.09 \\
\hline \multirow{13}{*}{ 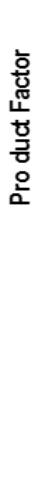 } & Internal Factor & House Design & 232 \\
\hline & & Age of Houses & 3.19 \\
\hline & & Houses Finishes & 3.70 \\
\hline & & Built up area/size & 3.00 \\
\hline & & No. of Room & 289 \\
\hline & & Type of houses & 2.94 \\
\hline & & Restriction of Interest & 3.98 \\
\hline & & Status of Houses & 3.81 \\
\hline & External Factor & Extemal View & 3.72 \\
\hline & & Density & 2.62 \\
\hline & & Landscaping & 264 \\
\hline & & Community management & 3.19 \\
\hline & & Open Spaces & 2.58 \\
\hline
\end{tabular}

4.4 Analysis on a status of living and housing mismatch attributes by using Pearson Chi-Square.

Table 4 shows the result from Pearson Chi-Square analysis on Status of living between owner and renter against overall elements. The preliminary test shows four elements contribute to the significant. For illustrations, credit history with 0.039 , Housing affordable supply (0.052), taxes (0.025) and community management (0.00). Rest of the attributes were exceeded to 0.05 .

Table 3: Analysis of Pearson Chi-Square

\begin{tabular}{|c|c|c|c|c|}
\hline \multicolumn{5}{|l|}{ Pearson Chi-Square Tests } \\
\hline Housing mismatch attributes & Analysis & Value & df & $\begin{array}{l}\text { Asymp. Sig. (2- } \\
\text { sided) }\end{array}$ \\
\hline Credit History & \multirow{4}{*}{ Pearson chi-square } & $10.087^{a}$ & 4 & .039 \\
\hline Housing affordable Supply & & $9.374^{a}$ & 4 & .052 \\
\hline Taxes & & $11.116^{a}$ & 4 & .025 \\
\hline Community management & & $21.257^{a}$ & 4 & .000 \\
\hline
\end{tabular}




\subsection{Discussion and analysis}

\subsection{Demographic Result}

The result of the finding shows the critical of studying disagreement of people towards several elements of housing mismatch in neighborhood areas. Although it is generally known that Kuala Lumpur increases negative in several cases. But, complete definition to delve deeper into community atmosphere should be created. The demographic result (tab. 1) indicate female (41.5\%), married people with $37.7 \%$, SPM and below (26.4\%), private institution (45.3), and monthly income with RM 2501-RM300 (22.6) respectively still act as a tenant. From the researcher perspectives, the profiles have become the paramount issues. The argument is; why and how the majority percentage of the local community still act as a tenant. The implementation of identifying the element that may contribute them for not purchasing houses are performing in the research. According to Gaspareneine (2014) claims that building factors, financial variable, demographic profiles, government, and developers are one of the main mechanism that affects housing prices. Hence, by providing this aspect, it will give the result of this studies more precisely.

\subsection{Analysis on Average value}

For table 2, shows at least, 18 from 36 elements contribute average value with more than 3.0, and the rest is vice versa. Kamaruddin \& Amin (2008) cited, the high value of average score are between $3.50-5.00$. The result shows suitable neighborhood (4.32) and popularity of location indicate highest average score among other elements. The mean can be interpreted as the balance score of the distribution. It is a descriptive statistic of the average index to explained on the highest rating among each variable. The other score that below than 3.00 are subjected to be the weak influence to people preference. The research concludes, things that promote the occurrence of an imbalance of housing supply and demand, whether surplus or shortage are from the sub-element contained in this studies. Such as, people are really affected by loan margin, external view, a status of houses and others. All this sub-element yet will influence their mind in purchasing residential houses.

\subsection{Summary of Pearson Chi-Square}

Pearson Chi-Square had been carried out to test the relationship between demographic factors and overall aspects. The researcher purposely wanted to study the relationship, or the significant between a status of living (owner and renter) with element consist in housing discrepancies. Is that actual "status of the living" will affect the existence of high proportion of housing imbalance? Tasir (2003) cited that, the significant value by Pearson Chi-square analysis must be less than 0.05 . From this preliminary result, the study indicates that only selected attributes have the significant relationship with the status of living (Tab. 3). The comparison made up by hypothesis created by the researcher in assuming that, there is no connection between these elements. The finding shows element for community management are most significant with the status of living rather than others because it stands at 0.00 as it correlated.

To summarize this discussion, the researcher identified the element by rating the value based on the mean score that cited by Kamaruddin \& Amin (2008), the attributes that actually give high influence to respondent will explain how much it will give impact to the people and its profiles. All the value that more than 3.0 (tab. 2) shows it affect the respondent. One of the most gives effect highly was suitable neighborhood and popularity of location recording with 4.32 and 4.49 respectively.

\section{Conclusion}

As the conclusion, the research conducted purposely to investigate relevant aspect that may create housing discrepancies by people profiles and preferences. The overall preliminary studies show there is few aspect that may consider by respondent and influence their decision making in buying houses. At least about eighteen elements contribute to the decision-making of respondent in decides for not buying homes. The methodology to achieve all objectives by conducted through primary and secondary data. For objectives number one, the implementation of sub-element had been studied by extensive literature. Secondly, data for demographic profiles had been separated to understand the relationship between the aspects. Finally, for the last objective, will determine its significance toward all the attributed that been faced by respondent.

The research conducted was based on the small sample of respondent represent as preliminary hypothesis thus enabling for future research to be undertaken. The researcher recommends improving the studies by producing framework model in future for particular areas. By doing this, all stakeholder can really know what kind of solution to overcome the housing imbalance in Malaysia.

\section{Acknowledgements}

The researcher acknowledges the other authors in this paper for giving tremendous support in completing this article. Many thanks to Dr. Rohayu Ab Majid, Prof. Dr. Ting Kien Hwa, Wan Intan Mastura and parents for understanding the limit of knowledge of the principal author. The researcher would also like to thank MyBrain15-KPT in giving the financial support in completing this paper.

\section{References}

A. Hamid Mar. (2006). Price-Contour Based Spatial DUmmy Variables for Segmenting Market in the Geographic INformation System Assisted Hedonic Modelling of Residential Property Prices. Malaysian Journal of Real Estate, 1(1), 39-57. 
Abdullah, H. (1992). Everything the condominium Developer should have told you. Pelanduk Publication (M) Sdn Bhd.

Ahmed, E., Shaqra ', A., Badarulzaman, N., \& Roosli, R. (2015). ScienceDirect Residents' Perception of the Affordability of Private Housing Schemes: Lessons from Aden, Yemen. Procedia -Social and Behavioral Sciences, 202(202), 389-399. http://doi.org/10.1016/j.sbspro.2015.08.243

Ariff, K., Omar, D., \& Mohd, Z. (2016). The Relationship between Youth Activities and Outdoor Features in Urban Neighbourhood Space. Procedia - Social and Behavioral Sciences, 234, 271-279. http://doi.org/10.1016/j.sbspro.2016.10.243

Ariff, K., Omar, D., Othman, S., \& Mohd, Z. (2016). Reviewing Youth Facility Requirements for Low-Cost Housing in. Procedia - Social and Behavioral Sciences, 222, 702-709. http://doi.org/10.1016/j.sbspro.2016.05.231

Bogdon \& Can. (1997). Indicator of local housing affordability : comparative and spatial approaches. Real Estate Economics, 25(1), 43-80.

Bramley, G. (2007). "The sudden rediscovery of housing supply as a key policy challenge." Housing Studies, 22(2), $22-41$.

Cagamas. (2013). HOUSING THE NATION ; Policies, Issues and Prospects. Cagamas Holdings Berhad.

DBKL. (2015). Dewan Bandaraya Kuala Lumpur. Housing Supply In Kuala Lumpur.

Dujardin, C. And Goffette-Nagot, F. (2005). Neighbourhood effects, public housing and unemployment in a French city.

Fawwaz, A., Saleh, A., Hwa, T. K., \& Majid, R. (2016). Housing Mismatch Model in Suburban Areas. Procedia - Social and Behavioral Sciences, 234, 442-451. http://doi.org/10.1016/j.sbspro.2016.10.262

Gobillon, L., Selod, H., \& Zenou, Y. (2007). The Mechanisms of Spatial Mismatch. Urban Studies, 44(12), 2401-2427. http://doi.org/10.1080/00420980701540937

Hamdan, H., Yusof, F., \& Marzukhi, M. A. (2014). AcE-Bs 2014 Sabah ASEAN Conference on Environment-Behaviour Studies The Social Capital and Quality of Life in Urban Neighborhoods High Density Housing. Procedia - Social and Behavioral Sciences, 153, 169-179. http://doi.org/10.1016/j.sbspro.2014.10.051

Hilmi, M., Hadi, A., \& Ibrahim, S. (2016). Review of Building, Locational , Neighbourhood Qualities Affecting House Prices in Malaysia. Procedia - Social and Behavioral Sciences, 234, 452-460. http://doi.org/10.1016/j.sbspro.2016.10.263

Hui, E. C. M., Zhong, J., \& Yu, K. (2015). Housing policy, work-residence mismatch and poverty concentration. Habitat International, 48, $198-208$. http://doi.org/10.1016/j.habitatint.2015.03.011

JPPH. (2016). Jabatan Penilaian dan Perkhidmatan harta Data Transaction. Kuala Lumpur.

KLSP. (2000). Kuala Lumpur Structure Plan 2020. DBKL. Retrieved from dbkl.com

Khazanah Research Institute Report. (2015). Making Housing Affordable. Malaysia: Khazanah Research Institute Publisher.

Leng, T. ai. (2015, December). Wangsa maju move up the value chain. Property Edge, p. 3.

Lisi, G. \& M. (2015). Estimating the housing price with a search-and-matching model. Journal of European Real Estate Research, 8(2), 107-129. http://doi.org/10.1108/JERER-09-2014-0035

Mulliner, E., Smallbone, K., \& Maliene, V. (2013). An assessment of sustainable housing affordability using a multiple criteria decision making method. Omega, 41(2), 270-279. http://doi.org/10.1016/j.omega.2012.05.002

Nawawi, A. H. (1999). Computer assisted Rating Valuation of Commercial and Industrial Properties in Malaysia ; Developing an Expert System from a Multiple Experts Knowledge Elicitation Methodology. Journal of Valuation and Property Services, 2(1), 13 - 38

NLIHC. (2016). No Refuge for Low Income Renters. Washington: JPmorgan Chase \& Co. Retrieved from www.NLHC.ORG/OOR

Safian, E., Nawawi, A. H., \& Sipan, I. (2014). Building and Locational Characteristic's Quality of Purpose-Built Office and their Relationship with Rentals. MPRA 64908(61160).

Seelig \& Phhibs. (2006). Beyond the normative : low income private renters' perspective of housing affordability and need for housing assistance. Urban Policy and Research, 24(1), $55-66$.

Stoll, M., Holzer, H. and Ihlanfeldt, K. (2000). Within cities and suburbs: racial residential concentration and the spatial distribution of employment opportunities across submetropolitan areas. Journal of Policy Analysis and Management, 19, 2017-231.

Štreimikienè, D. (2014). Housing Indicators for Assessing Quality of Life in Lithuania. Intellectual Economics, 8(1), 25-41. http://doi.org/10.13165/IE-14-8-1-02

Tasir, M., \& M.S, A. (2003). Analisis Data Berkomputer SPSS 11.5 for windows. Kuala Lumpur: Vendon Publishing.

Thalmann, P. (2003). "House poor" or simply "poor"? Journal of Housing Economics, 12(4), 291-317. http://doi.org/10.1016/j.jhe.2003.09.004

Wan Nor Azriyati, N. Hani, Z. M. (2007). Public-private partnerships approach: A success story in achieving democracy in the home ownership for urban inhabitants in Kuala Lumpur Malaysia. REAL CORP 007.

Zhou, S. H., Wu, Z. D., \& Cheng, L. P. (2013). The Impact of Spatial Mismatch on Residents in Low-income Housing Neighbourhoods: A Study of the Guangzhou Metropolis, China. Urban Studies, 50(9), 1817-1835. http://doi.org/10.1177/0042098012465906 